\title{
The mediating role of self-esteem on the relationship between emotional dysregulation and compassion with Internet addiction
}

\author{
Ghasem Abdolpour ${ }^{1}$, Behzad Shalchi ${ }^{2}$, Sirvan Hamzezadeh ${ }^{3}$, Ali Salehi ${ }^{4}$ \\ 1-PhD, Clinical Psychology, School of Psychology and Educational Sciences, University of Shahed, Tehran, Iran \\ (Corresponding Author). ORCID: $\quad$ E-mail: g.marand@yahoo.com \\ 2- PhD, Psychology, School of Psychology and Educational Sciences, Azarbaijan Shahid Madani University, \\ Tabriz, Iran. \\ 3- MSc, in Psychology, Department of Clinical Psychology, School of Behavioral Sciences and Mental Health, \\ Tehran, Iran. \\ 4- MSc, in Psychology, Department of Clinical Psychology, School of Behavioral Sciences and Mental Health, \\ Tehran, Iran.
}

Received: 27/03/2019 Accepted: 14/05/2019

\begin{abstract}
Introduction: Internet addiction is a behavioral dependency that person to deal with problems than it uses.

Aim: The aim of this study was to investigate the role of mediator Self-esteem in the relationship among emotional dysregulation and compassion with Internet addiction.

Method: In a descriptive-correlation study, a sample of 240 students from Iran University of medical sciences was selected using cluster sampling method. Participants responded to SelfCompassion scale, Self-Esteem Scale, Difficulties in Emotion Regulation Scale (DERS), Internet addiction Scale. Data were analyzed using Structural Equation Modeling (SEM). For statistical analysis, Spss V. 22 and Lisrel 8.85 were used to classify, process and analyze the data and to investigate the hypotheses of the research.

Results: The evaluation of hypothetical model with fit indexes demonstrated that the hypothetical model fits the measurement model $(\mathrm{CFI}=0.98, \mathrm{NFI}=0.98$, and RMSEA=0.055). Structural relations analysis also showed emotional dysregulation and compassion indirectly through Self-Esteem over Internet addiction respectively (0/73, -0/126) and also the results also showed that the emotional dysregulation has a direct relation to Internet addiction (0/44).

Conclusion: Research findings showed that Self-Esteem have a mediating role in relationship between emotional dysregulation and compassion and Internet addiction. Considering these dimensions and the effectiveness of the employed mechanisms can be useful in developing efficacious preventive and therapeutic interventions for Internet addiction.
\end{abstract}

Keywords: Compassion, Self-Esteem, Emotional dysregulation, Internet addiction

\footnotetext{
How to cite this article : Abdolpour Gh, Shalchi B, Hamzezadeh S, Salehi A. The mediating role of self-esteem on the relationship between emotional dysregulation and compassion with Internet addiction. Shenakht Journal of Psychology and Psychiatry. 2019; 6 (3): 129-143 URLhttp://shenakht.muk.ac.ir/article-1-500-fa.pdf
}

Copyright $\odot 2018$ the Author (s). Published by Kurdistan University of Medical Sciences. This is an open access article distributed under the terms of the Creative Commons Attribution-Non Commercial License 4.0 (CCBY-NC), where it is permissible to download, share, remix, transform, and buildup the work provided it is properly cited. The work cannot be used commercially without permission from the journal. 


\section{نقش واسطه كرى عزت نقس در رابطه شفقت به خود و دشوارى در تنظيم هيجان با اعتياد به اينترنت}

\section{قاسم عبدل يور'، بهزاد شالجى'، سيروان حمزهزاده'، على صالحى"}

ا.دانشجوى دكترى روان شناسى بالينى، گروه روان شناسى بالينى، دانشكده علوم تربيتى و روان شناسى، دانشكاه شاهد، تهران، ايران (مولف مسئول). ايميل:

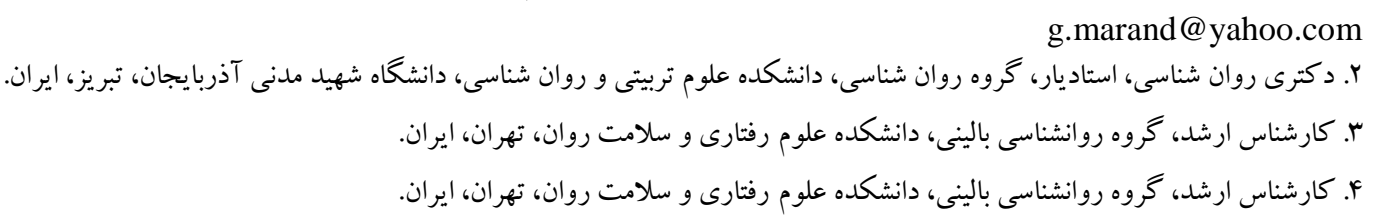

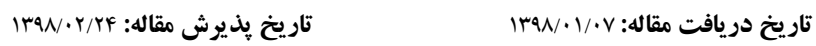

جكيده مقدمه: اعتياد به اينترنت، نوعى وابستخى رفتارى است كه فرد براى مقابله با مشكلات از آن استفاده مى كند. هدف: هدف يزوهش حاضر، بررسى نقش واسطه اى عزت نفس در رابطه بين شفقت به خود و دشوارى در تنظيم هيجان با اعتياد به اينترنت بود.

روش: طرح يزٔوهش حاضر، از نوع توصيفى همبستكى است. براى اين منظور، 240 نفر از دانشجويان دانشكاه علوم يزشكى ايران با

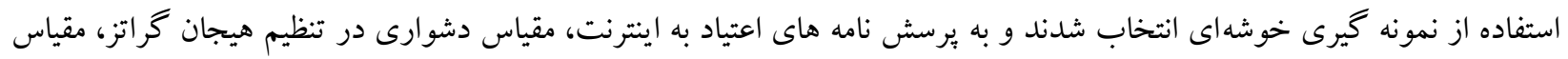

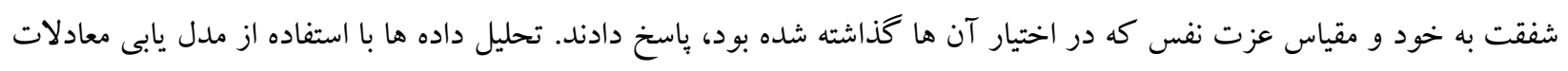

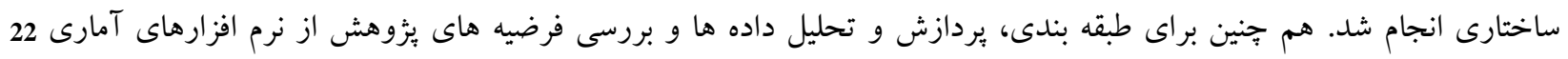

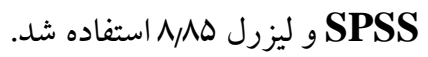

يافته ها: ارزيابى مدل فرضى بِزوهش با استفاده از شاخص هاى برازندگى نشان داد كه مدل فرضى با مدل اندازه گيرى، برازش دارد

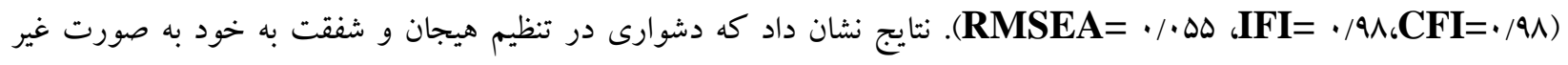

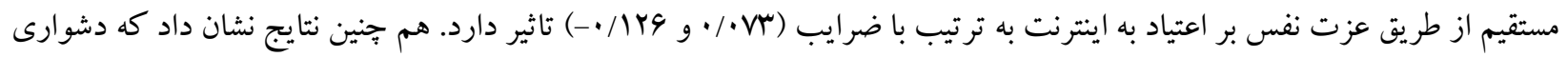
در تنظيم هيجان رابطه مستقيم با اعتياد به اينترنت (FF/•)، دارد.

نتيجه كيرى: نتايج بزوهش نشان داد كه عزت نفس در رابطه بين دشوارى در تنظيم هيجان و شفقت به خود نقش واسطه ایى دارد.

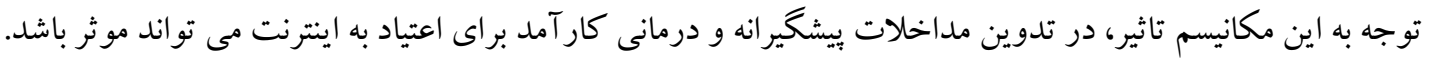
كليدوازه ها: دشوارى در تنظيم هيجان، شفقت به خود، عزت نفس، اعتياد به اينترنت 
مىشود. Y تا r درصد از ميان ·ل درصد معتادان به

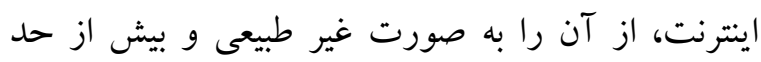
معمول استفاده مى كنتد (اورسال، اورسال، آنسال و و

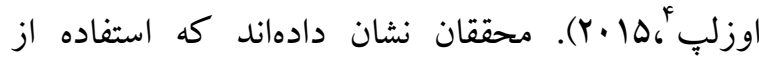
اينترنت در حال تبديل شدن به يكك فعاليت خانكى است

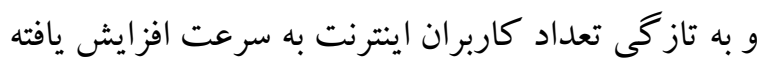
است، به طورى كه بر آورد فعلى كه در سال ها •r در جهان انجام گرفته معادل r, r ميليارد نفر كاربر اينترنتى

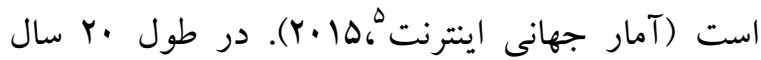
كذشته، تكنولوزى اينترنت آسايش بزركى را براى زندگى مدرن به ارمغان آورده است. با اين حال استفاده بيش از حد از اينترنت ممكن است به اعتياد به اينترنت منجر شود كه مى تواند مشكلات جدى از قبيل مشكلات جسمى و روانى به دنبال داشته باشد و كاركرد روانى -

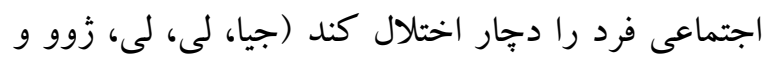

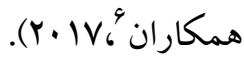
با توجه به گسترش و فراگير شدن استفاده از اينترنت در جامعه ايران به ويزه در قشر دانشجو به نظر مىرسد با افزايش روزافزون استفاده از اينترنت مىتواند بهداشت روانى و جسمانى جوانان را متأثر ساخته و در آينده شاهد معضلات ناشى از اعتياد به اينترنت باشيم. از جمله هزينه-

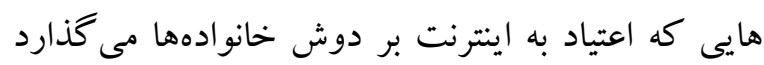
فارغ از هزينههاى اقتصادى، هزينههاى روانى نيز در بر -

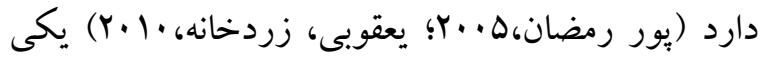
از عواملى كه ارتباط نزديكى با رفتارهاى اعتيادى دارد خود تنظيمى هيجانى است. خود تنظيمى يا به عبارت ديخر كنترل خود، تلاش سازمان يافته در جهت تنظيم افكار، مقلdمه اينترنت بهعنوان بخش جدايى نايذيرى از زندكى روزانه مردم در جهان معاصر در نظر گرفته شده است كه استفاده از آن هر روزه در حال گسترش است و به طور گسترده در زمينههاى مختلف زندكى از جمله آموزش و برورش، فعاليتهاى علمى، تبادل اطلاعات، ارتباطات بين فردى،

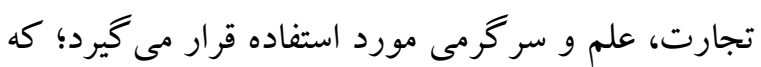
علت در دسترس بودن و قيمت ارزان آن در خانه ها، مدارس، دانشگاه ها، كتابخانه ها و كافى نت ها منجر به استفاده از اين فناورى شده است (ملكك، خليفه و

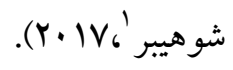
همزمان با دسترسى كستردهى افراد به اينترنت، شاهد نوع جديدى از اعتياد، يعنى اعتياد اينترنتى هستيم كه مسئله خاص عصر اطلاعات است. همانند انواع ديخر اعتياد، اعتياد به اينترنت ‘ نيز با علائمى هم جون اضطر اضطراب،

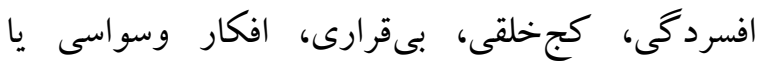
خيالبافى راجع به اينترنت همر اه است، اعتياد به اينترنت يا

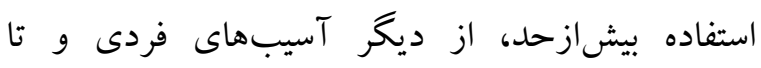
حدودى اجتماعى اينترنت است كه كاهى از اين بيمارى تحت عنوان اعتياد مجازى و مشهورتر از آن با عنوان (اعتياد به اينترنت) نام برده مى شود (يى بينگك، شِن، وى له،

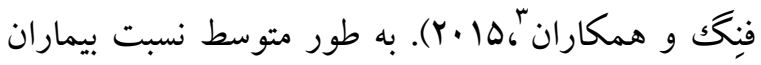

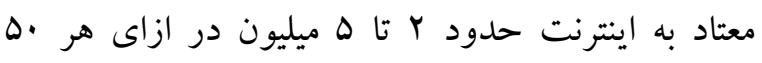
ميليون استفاده كننده معمولى هستند، به عبارتى مىتوان كفت تقريباً ه تا •ا دروصد استفاده كنند أنان از اينترنت دجار مشكل اعتياد هستند، همين نسبت در ميان مصرف كنند كان مشروبات الكلى و قماربازى نيز ديده

${ }^{6} \mathrm{Jia}, \mathrm{Li}, \mathrm{Li}$, Zhou \& etal
} 


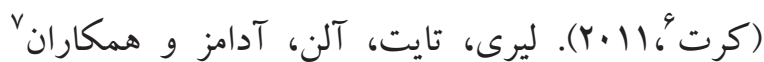
(Y.V.V) روبرو مى شود و يا رويدادهاى منفى زندگى كذشتهاش را به خاطر مى آورد در اين شرايط از طرف خود نيز بازخوردهاى منفى را دريافت مى كند. در اين شرايط سطح بالاى شفقت نسبت به خود، از افراد در برابر احساس منفى نسبت به خود و احساس استرس و يا شرايط زندگى منفى حمايت كرده و سبب مىشود كه افراد نسبت به خودشان مهربان بوده و به زندكى اميدوار شوند و معنايى دوباره از زندگى يبدا كنند. بريانسيس و جين

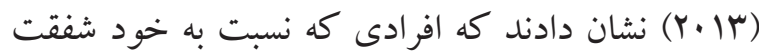
بالاترى دارند، قدرت بهبود بخشيدن ضعفها، اصلاح مشكلات اخلاقى و جالشهاى خودشان در آنها بيشتر بوده و همجِين شفقت نسبت به خود توان عشق ورزيدن و مهربانى را نسبت به ديخران در آنها ايجاد مى كند. يخوهشهاى قبلى معمولاً تأثيرات آسيبهاى روانى رابر

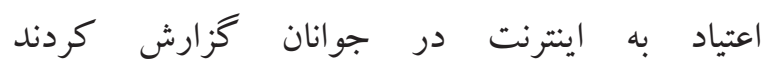

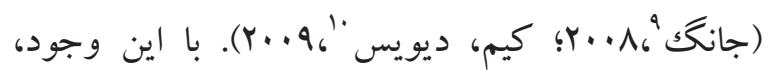
توجه كمترى به تأثيرات واسطهاى ميان آسيبهاى روانى و اعتياد به اينترنت شده است. به ويزٔه ديويس (1 (YY)، بيان كرد كه اكرجه آسيب هاى روانى علتهاى دورى هستند، آنها به طور غيرمستقيم از طريق شناختهاى ناساز كار، اعتياد به اينترنت را تحت تأثير قرار مىدهند. مدل شناختى- رفتارى مشكلات استفاده از اينترنت، جارجوبى را براى درك سببش سناسى اعتياد به اينترنت فراهم كرده است. اين مدل فرض مى كند كه مشكلات استفاده از اينترنت توسط شناختهاى ناكار آمد در ارتباط

${ }^{6}$ Kret

${ }^{7}$ Leary, Tate, Allen, Adams \& etal

${ }^{8}$ Breines JG, Chen

${ }^{9}$ Jang, K. S., Hwang, S. Y., \& Choi

${ }^{10}$ Kim, H. -K., \& Davis
احساسات و اعمال به منظور دستيابى به اهداف خاص

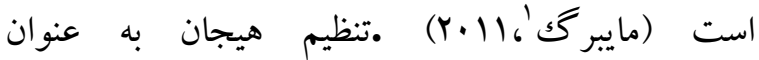
فر آيندهايى كه از طريق آنها افراد هيجاناتشان را براى باسخ به توقعات محيطى هشيارانه و ناهشيارانه تعديل مى كنند، در نظر كرفته مىشود (آدائو، نالن هاكسما و

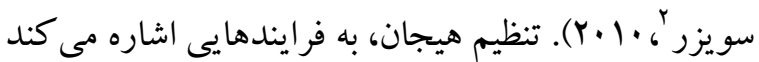
كه بهوسيلهى آن ما بر اين كه جֶه هيجاناتى را تجربه كنيم، جهه موقع آنها را تجربه كنيم و جِكونه آنها را بيان

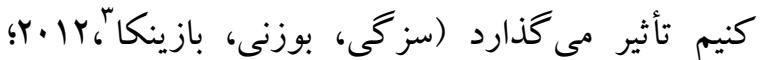
Tمستادر نشان دادند كه هيجان خواهى بر اعتياد به اينترنت اثر

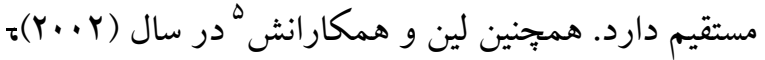

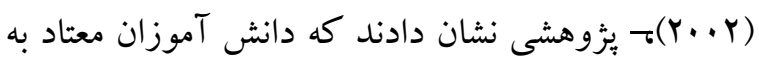
اينترنت در بعد مخاطره جويى و هيجان، نمرات بالاترى از دانشجويان غير معتاد به دست آوردند. اميرى و همكاران در يُزوهش خود به اين نتيجه دست يافتند كه تنظيم هيجان اهميت ويزهاى در تبيين اعتياد به اينترنت داشته و مىتواند نقش مؤثرى در كرايش به سمت درگيرى در رفتارهاى اينترنتى داشته باشند (اميرى،

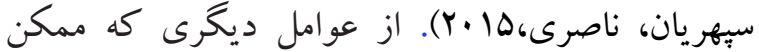
است با اعتياد به اينترنت ارتباط داشته باشد، شفقت به خود است. شفقت نسبت به خود باعث افزايش بازيابى و ساز گارى در آنها شده و سبب مىشود تا احساس امنيت، بيوستگى و آرامش هيجانى كنند. اين عوامل باعث افزايش بهزيستى فرد شده و لذا خواهد توانست بيمار را به عنوان فردى جداى از استرس و فرسودگى در محيط كار در نظر گرفته و لذا كيفيت مراقبت ارائه شده افزايش يابد

\footnotetext{
${ }^{1}$ Myberg

${ }^{2}$ Aldao, Nolen-Hoeksema \& Schweizer

${ }^{3}$ Szczygie D, Buczny J, Bazinska

${ }^{4}$ Amsadter

${ }^{5}$ Leen S, Tessai
} 
مهمترين جنبههاى شخصيت و تعيين كننده ويز كىهاى

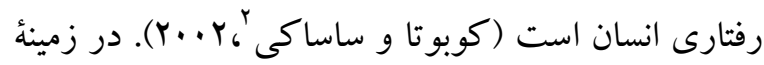

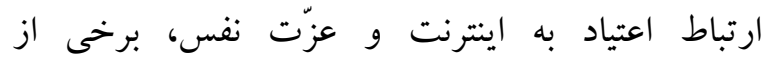

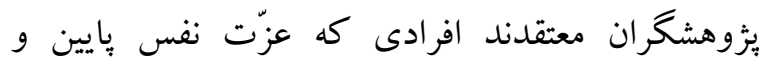
مهارتهاى اجتماعى كمى دارند، احتمال بيشترى دارد كه در فضاهاى مجازى، ابتكار عمل و كنترل را به دست بحيرند و احساس هويت و جايگاهى را كه در زندكى

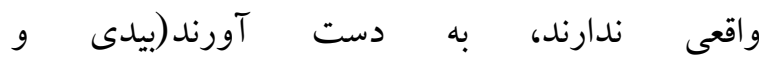

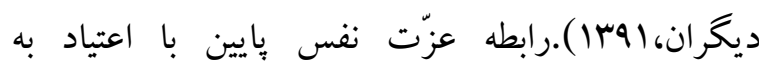
اينترنت، در تحقيقات متعددى تأييد شده است (يانگك و

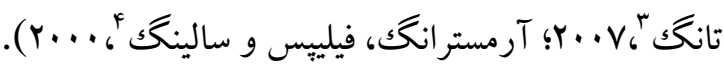
در برخى از ئزوهش ها نيز مشخص شده كه استفاده از

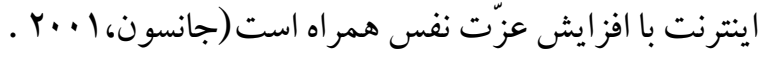
لذا نياز افراد به ايجاد برداشت مثبت از خود يا افزايش عزّت نفس مى تواند آنها را به سوى استفادهُ بيشتر و ولئ افراطى از فضاهاى مجازى، شركت فعالتر در يروفايلهاى شخصى در فضاى اينترنتى رهنمون كند علىرغم اهميت اين مدل، مطالعات اندكى، مدل شناختى رفتارى مشكلات استفاده از اينترنت را به كاربرده است (ديويس، (Y...). بر اساس مدل شناختى رفتارى اعتياد به اينترنت، اين مطالعه به بررسى اثر مستقيم دشوارى در تنظيم هيجان و شفقت به خود و همجنين اثرات واسطهاى شناختهاى ناساز گارى كه شامل افكارى كه باعزت نفس مرتبط است بر اعتياد به اينترنت برداخته است. در اين هئوهش مدل زير (شكل () تدوين شد تا مشخص شود آيا عزتنفس در رابطه بين شفقت به خود و

${ }^{2}$ Kubota \& Sasaki

${ }^{3}$ Yang \& Tung

${ }^{4}$ Armstrong, Phillips \& Saling
با رفتارهايى كه ياسخهاى ناساز گار را تقويت و تداوم مىبخشند، ايجاد مىشوند. به طور خاص در اين مدل، علتهاى دور و نزديكك كه در مشكلات استفاده از اينترنت نقش دارد، معرفى شده است. آسيبهاى روان شناختى مثل افسردگى و اضطراب اجتماعى از جمله علل سهيم در مشكلات استفاده از اينترنت است. با اين حال جيزى كه مهم است و بايستى توجه خاصى شود، اين است كه آسيب شناسى روانى هرجّند علل ضرورى است ولى بهخودى خود منجر به اعتياد به اينترنت نمىشود. بلكه به جاى آن، مشكلات روان شناختى افراد را مستعد مى كند تا شناخت هاى ناساز گار كه منجر به نقص كنترل مىشود را توسعه دهند. شناخت ناساز گار يكك علت مبنايى و كافى براى مشكلات استفاده از اينترنت است و به عنوان افكار تحريفشده درباره خود و دنيا تعريف شده است. اين افكار درباره خود شامل ديد گاه منفى درباره خود مثل خودكارآمدى پيايين، شك و ترديد نسبت به خود و خودارزيابى منفى و عزت نفس بايين است. عزت نفس بديدهاى روانشناختى است كه تأثير قاطعى بر ابعاد عاطفى و شناختى انسان دارد و كاركرد آن در مقابله با فشارهاى زندكى به عنوان يكك منبع مؤثر و مهم شناخته مىشود. از آن جا كه عزت نفس قطعى ترين عامل در روند رشد روانى فرد محسوب مىشود، هر اندازه كه فرد در كسب عزت نفس دجار شكست شود، دستخوش اضطراب، آسيبِيذيرى روانى، بدكمانى از خود و احساس عدم كفايت از زندگى مى گردد (مكوالى،

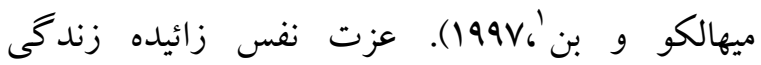
اجتماعى و ارزشهاى آن است و در تمامى فعاليتهاى روزانه انسان به نوعى جلوه

${ }^{1}$ Mcauley, Mihalko \& Bane, 
دشوارى در تنظيم هيجان با اعتياد به اينترنت نقش

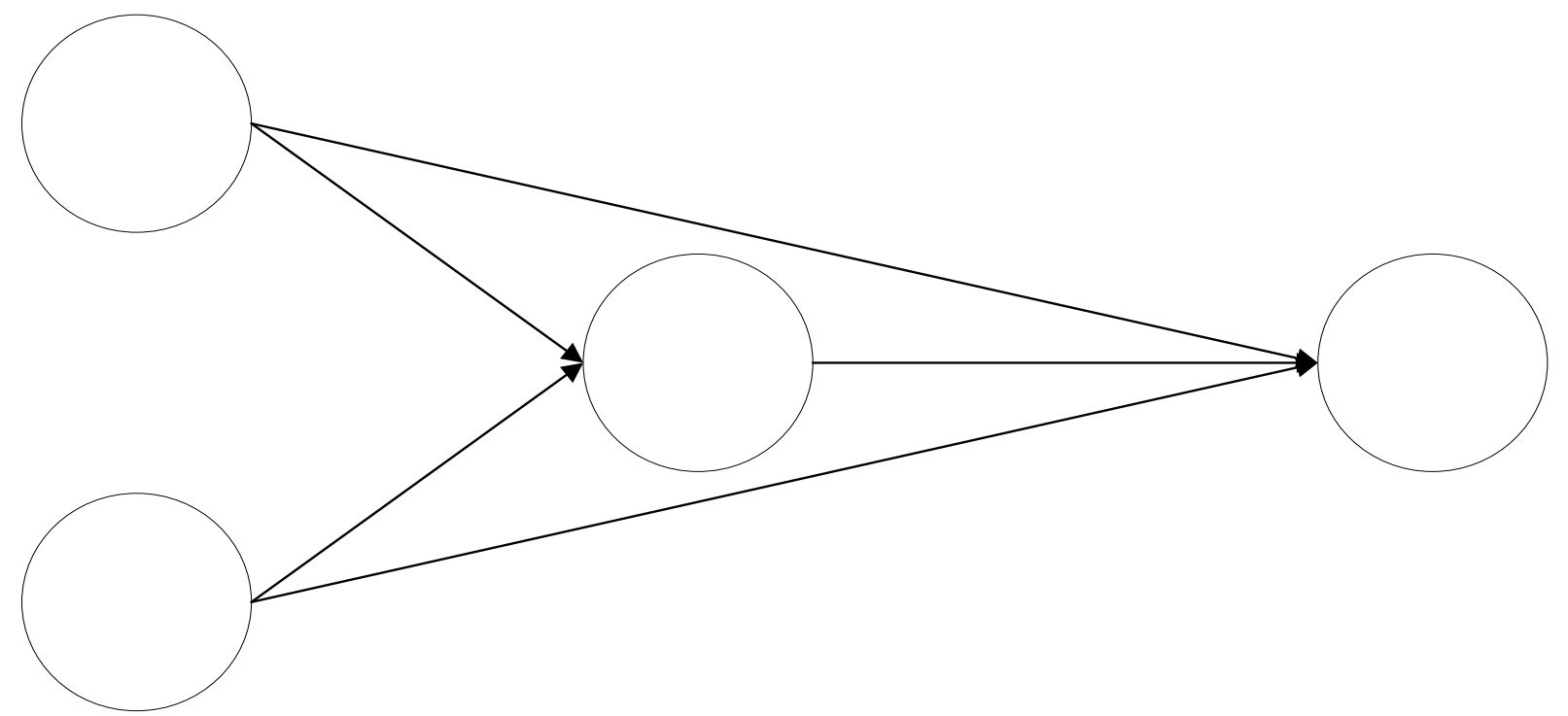

شكل 1 مدل مفهومى يزوهش

بهداشت جهار دانشكده انتخاب شدند و سبس از ميان دانشجويان اين دانشكدهها افرادى به صورت تصادفى در

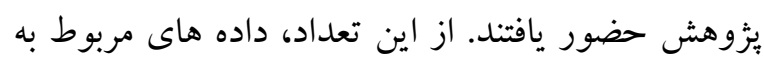
rF. روىدادههاى آنها انجام شد.

ابز ار ابز ارهاى يزوهش به شرح زير بودند: مقياس خود شفقت ورزى (SCS): اين مقياس يكك ابزار

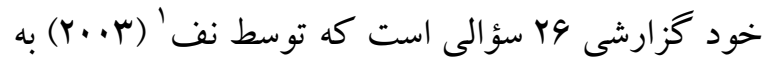
منظور سنجش ميزان خود شفقت ورزى ساخته شده است. اين مقياس داراى 9 خرده مقياس مهربانى با خود، قضاوت در مورد خود، احساسات مشترك انسانى، منزوى سازى، ذهن آكَاهى و بزر گنمايى است. تحقيقات كوناكون بيانگر اين است كه اين ابزار از اعتبار همزمان،

${ }^{1}$ Neff
روش اين يزوهش به لحاظ هدف، از نوع بنيادى و به لحاظ نحوه گردآورى دادهها، از نوع توصيفى -همبستخى است. جامعه آمارى يزوهش، همه دانشجويان دانشگاه علوم يزشكى ايران در سال تحصيلى 99-9V را شامل مىشود.

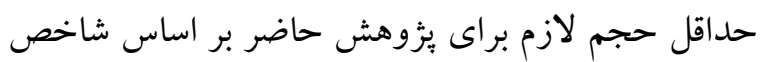
ير كاربرد N بحرانى هولتر محاسبه شده است كه اين مقدار براى مدل فرضى يثزوهش و بر اساس متغيرهاى مكنون و مشهود برابر IN/IF با در نظر كرفتن حداقل حجم مورد نياز هنگامى كه متغيرهاى مشهود مدل (در مدل فرضى يزوهش حاضر، إن

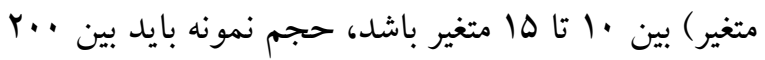
تا..F نفر باشد (كلاين، •(Y). از اين رو، كل نمونه انتخاب شده در اين بثوهش ·rV نفر است. با استفاده از

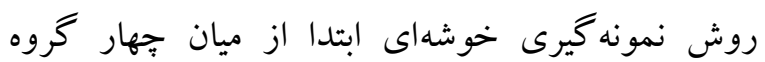

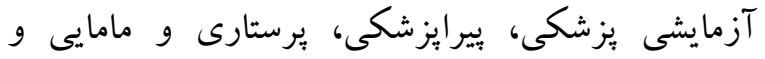


اينترنت است. اين برسشنامه مداد كاغذى شامل ·r ماده

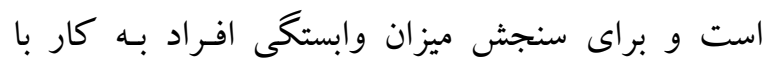
اينترنت يا كامييوتر توسط كيمبرلى يانگك تهيه شده است

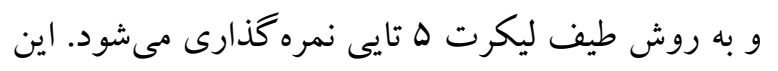
آزمون توسط اورنگك (سمبا) بـه فارسى ترجمه و مورد

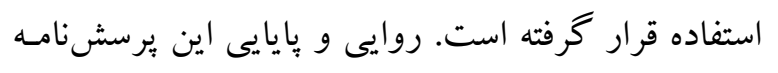
در يُوهشهاى جندى ذكر شده است. به عنوان مثال،

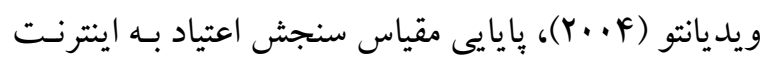

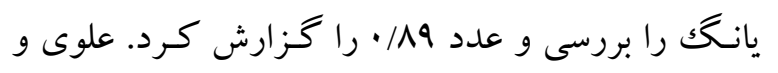

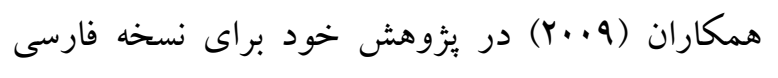
برسشنامه ينج عامل ("صرف زمان بيشازحد در اينترنت)، "استفاده از اينترنت جهت كسب آرامش درونى")،

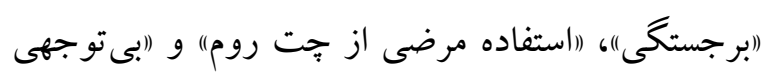
به وظايف شغلى و تحصيلى" را استخراج نمودهاند؛ و و ولاوه علاوه بر اين، براى اين برسشنامـه سه نوع بِيايى

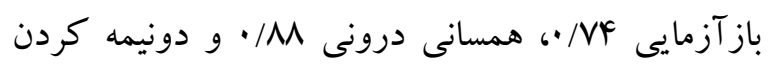

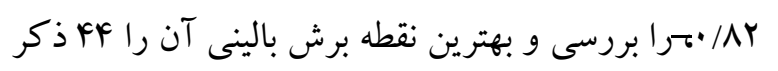
كردماند.

مقياس عزتنفس روزنبركك: اين مقياس شامل · •1 ماده خود گزارشى است و هر گزاره اين مقياس، شامل يك مقياس جهارگزينهاى (از كاملاً موافقم تا كاملاً مخالفم)

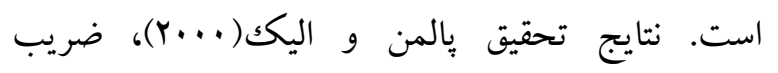
همبستگى باز آزمايى آن را در فاصله زمانى دو هفته،

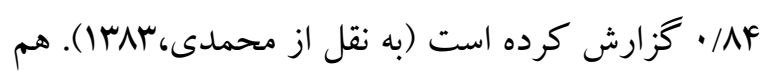
جنين محمدى (r/Hו)، شاخصهاى روانسنجى اين مقياس را در جامعه ايران بررسى كرده و اعتبار اين مقياس را از طريق روش آلفاى كرونباخ، بازآمايى و دونيمه

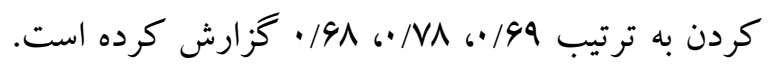
به علاوه با مقياس عزت نفس كوير اسميت 191 .
همخرا و تمييزى خوبى برخوردار است و يايايى آزمونباز آزمون آن نيز قابلقبول است. آلفاى كرونباخ كلى اين

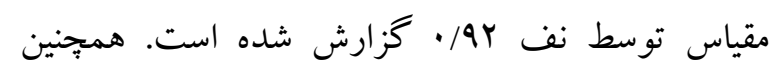

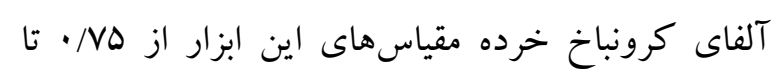

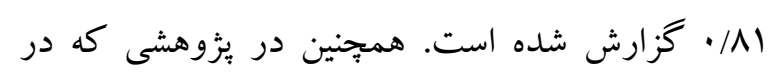

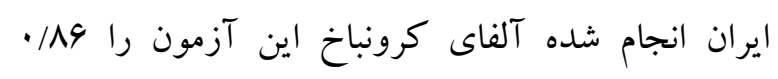
كزارش دادهاند و خرده مقياسهاى اين آزمون نيز از از همسانى بالايى برخوردار بودند (خسروى و همكاران .(Irar مقياس دشوارىهاى تنظيم هيجانى (DERS): يكك

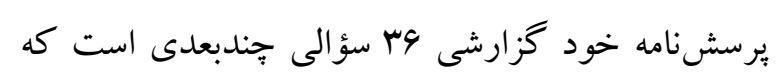

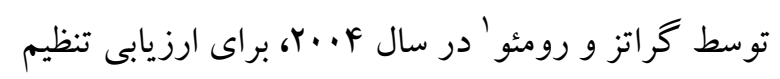
هيجانى و مشكلات تنظيم هيجان ساخته شده است. اين يرسشنامه داراى شش خرده مقياس عدم يذيرش بِاسخ هاى عاطفى، اختلال در انجام رفتارهاى هدفمند، اختلال

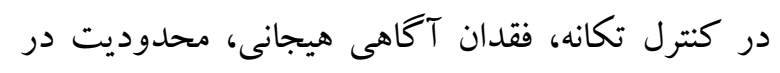
دستيابى به راهبردهاى تنظيم هيجان و فقدان شفافيت

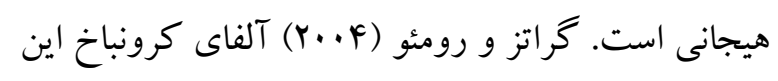

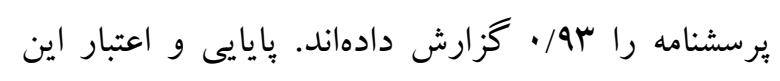
يرسشنامه در ايران توسط امينيان (IMNA) مورد ارزيابى

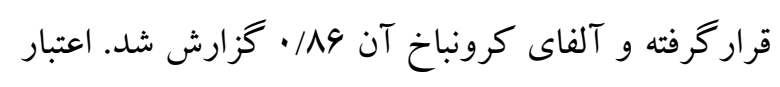
همزمان اين برسشنامه هم سنجيده شده است كه براى اين منظور نمره يرسشنامه مذكور با نمره برسشنامه هيجان

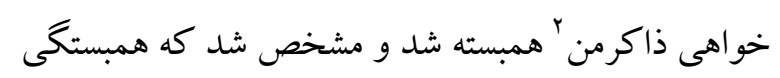
مثبت معنى دارى بين اين آنها وجود دارد؛ و اين نشان از اعتبار مقياس دشوارىهاى تنظيم هيجانى است.

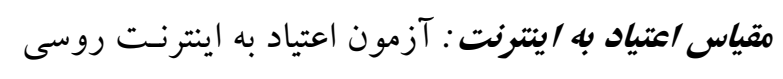

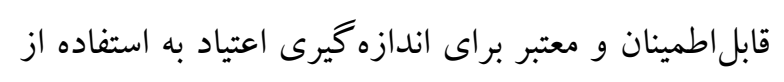

${ }^{1}$ Gratz \& Roemer

${ }^{2}$ Zakerman 
شده است. همان گونه كه مندرجات اين جدول نشان مى

دهند تمامى همبستخى هاى مقدار قابل تو جهى را شامل مىشوند (ه\&q فكرى و افسردكى بيشترين همبستخى (r=•/DFq) و عدم

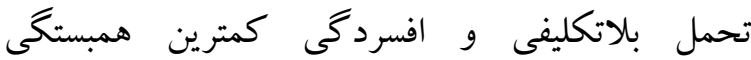

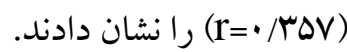

همبستخى معنادار مثبت دارد. در اين يثوهش آلفاى كرونباخ VD/ به دست آمد.

يافتهها در جدول ا، ماتريس همبستخى بين متغيرهاى مكنون، ميانگين و انحراف استاندارد متغيرهاى بثزوهش نشان داده

\begin{tabular}{|c|c|c|c|c|c|c|}
\hline ميانكين (انحراف استاندارد) & $\varphi$ & 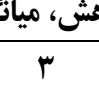 & r & $\frac{1}{1}$ & جدول | ماريس & \\
\hline$V r / F \mid \cdot(1 N / .91)$ & & & & 1 & دشوارى در تنظيم هيجان & 1 \\
\hline$F V / 9 \Delta \Delta(11 / q V \cdot)$ & & & 1 & $\cdot / 4 \cdot 9^{* * *}$ & شفقت به خود & r \\
\hline $\mid r / \Lambda \Delta F(Q / r \Delta \Delta)$ & & 1 & $\cdot / \Delta F q^{* * *}$ & $\cdot / \pi \Delta V^{* *}$ & عزت نفس & r \\
\hline$r r / 9 V \Delta(\Delta / q \mid r)$ & 1 & - $/$ FTV & $\cdot / 49 Y^{* * * *}$ & - $/$ FFY*** & اعتياد به اينترنت & p \\
\hline
\end{tabular}

فرض نرمال بودن جندمتغيرى با محاسبه شاخص كشيدگى جندمتغيرى نسبى " بررسى شد كه مقدار آن برابر •^•/| به دست آمد. بنتلر (1990)، معتقد است درصورتى كه ارزش اين شاخص بيشتر از ب نباشد، نرمال بودن جندمتغيرى محقق شده است؛ بنابر اين توزيع تمامى تركيبهاى متغيرها نرمال است. ييش فرض عدم وجود

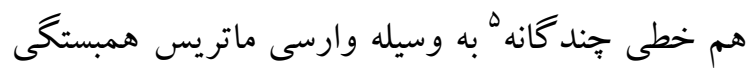
بين متغيرهاى مشهود انجام شد. بررسى اين ماتريس حاكى از عدم وجود هم خطى جند

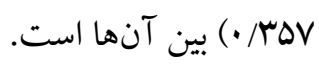

قبل از ارزيابى مدل اندازهگيرى و مدل ساختارى، ييشفرضهاى مهم مدليابى معادلات ساختارى شامل

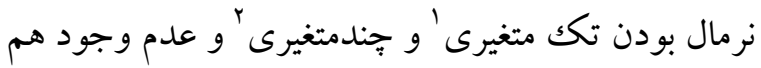
خطى جند گانه مورد بررسى قرار گرفت. در اين مطالعه جولكى متغيرهاى مشاهده يذير در دامنه

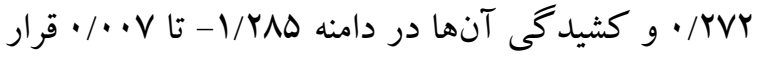

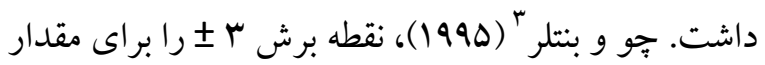
جولكى مناسب مىداند. اگر جهه توافق اندكى درباره نقطه برش كشيدگى وجود دارد، با اين حال به طور كلى مقادير بيش از · ل \براى اين شاخص مسئله آفرين بوده

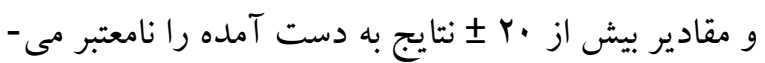

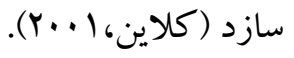

1. univariate normality

2. multivariate normality

3. Chou \& Bentler 
جدول r شاخصهاى برازش مدل اندازهكيرى و مدل ساختارى يزوهش

\begin{tabular}{|c|c|c|c|c|c|c|c|c|}
\hline & & & $S$ & $\boldsymbol{R}$ & ; & & ( & \\
\hline$\cdot / 99$ &.$/ 91$ & . &.$/ \cdot \Delta F$ & $.1 \cdot \Delta q$ & $1 / 991$ & $\Delta q$ & $|\cdots / r|$ & مدل اندازهكيرى \\
\hline.$/ 90$ &.$/ 91$ &.$/ 94$ & $\cdot / \cdot 01$ & $\cdot / \cdot \Delta \Delta$ & $1 / \Delta 9$ & FA & VA/VD & مدل ساختارى \\
\hline
\end{tabular}

ضرايب استاندارد به تصوير مى كشد. همان كونه كه

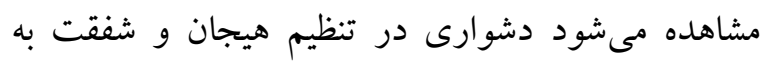
خود به عنوان متغيرهاى برون زا، به ترتيب با ضريب t-)0/44، (t-values= -2/52) -0/28 $-،(t-v a l u e s=4 / 09) 0 / 49, \quad($ values $=4 / 27$ (t-values= = -1/93)0/24 بر عزتنفس، اعتياد به اينترنت دارد. عزتنفس نيز با ضريب استاندارد 0/26- ) (t-values= -1/99 بر اعتياد به اينترنت تأثير مى كذارد. با توجه به اينكه در مدل ساختارى، معنادارى ضريب مسير با استفاده از مقدار T-value) T مشخص مىشود. جنانجه مقدار t بيش از 199/ باشد ارتباط دو سازه معنادار

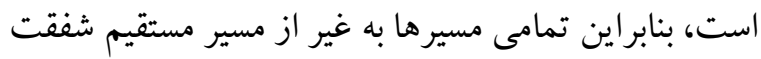

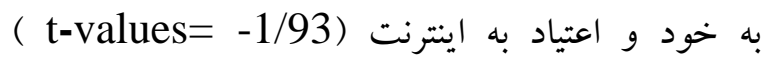
معنادار است.

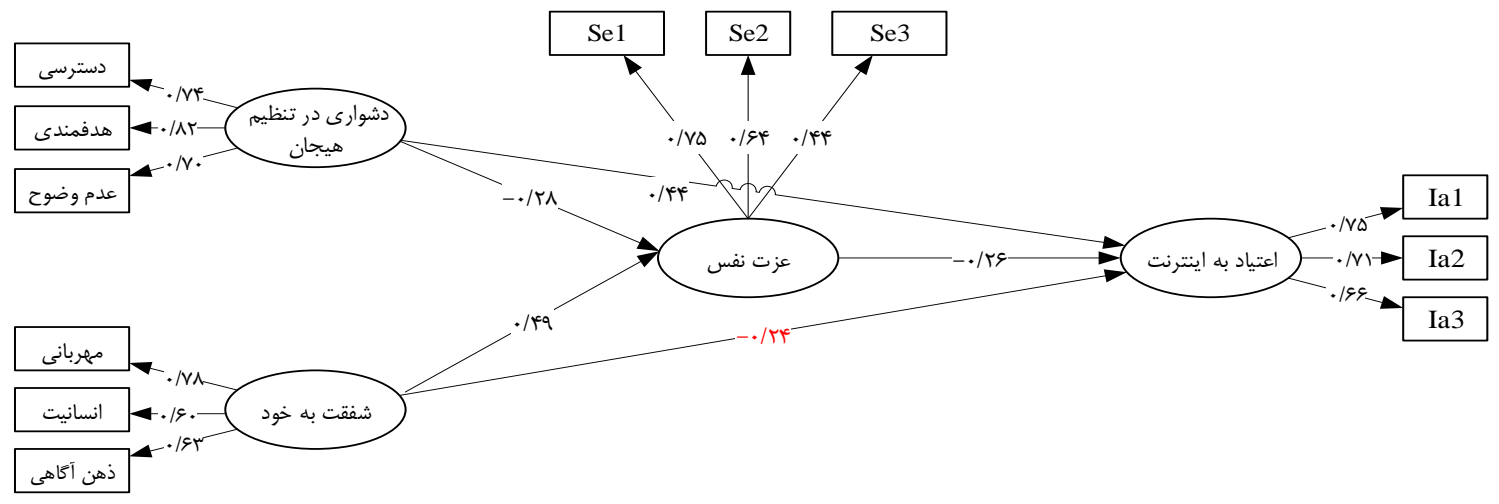

شكل r مدل ساختارى يزوهش
شاخصهاى برازش مدل اندازهيرى كه در جدول r ارائه شده است، برازش مطلوب اين مدل را نشان مىدهد؛ بنابراين متغيرهاى مشهود توانايى لازم براى عملياتى كردن متغيرهاى مكنون را دارند. دادهاى يُزوهش حاضر از مدل مفهومى تحقيق حمايت مى كنند. تمام شاخصهاى تطبيقى، شاخص برازش مقايسهاى و نيز نزديكك به

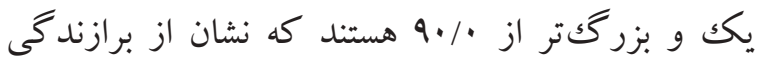

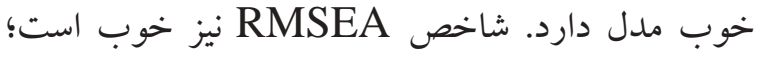
بنابر اين شاخصهاى مقتصد نشان مىدهند كه اقتصاد مدل

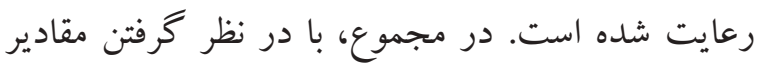
تكتتك اين شاخصها، بايد كفت مدل مفروض اين تحقيق برازش خوبى دارد. همجينين ارزيابى مدل ساختارى با استفاده از روش مدرد دارد يابى معادلات ساختارى نشان داد كه تمامى شاخصهاى برازش اين مدل فرضى در محدوده برازش مطلوب قرار

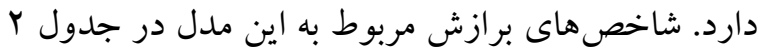
ديده مىشود. شكل 1 مدل ساختارى مفهومى را به همراه 
مسير على غيرمستقيم معنىدار خواهد بود. مندرجات

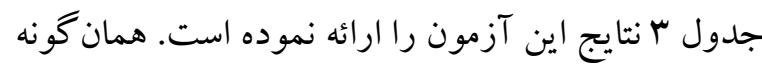
كه مندرجات جدول ب نشان مىدهد مسير دشوارى در تنظيم هيجان و شفقت به خود به اعتياد به اينترنت با

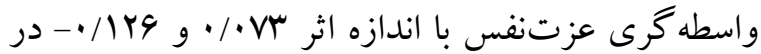
سطح ه•/ > > معنى 1 مار است.
در مطالعه حاضر براى ارزيابى روابط واسطهاى از آزمون بوت استربٍ استفاده شد. زمانى كه تعداد نمونه جندان زياد نباشد، بوت استرٍ قدرتمندترين و منطقىترين روش براى دست يابى به اثرات غير مستقيم را فراهم مى -

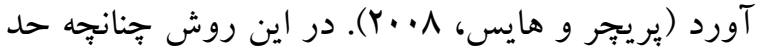
بالا و ويايين اين آزمون هردو مثبت يا هردو منفى باشند و مقدار صفر مابين اين دو حد قرار نكيرد در آن صورت نورن

جدول r نتايج آزمون بوت استرب براى روابط واسطهاى

\begin{tabular}{|c|c|c|c|c|c|c|c|}
\hline \multirow{2}{*}{ معنى سطح } & \multirow{2}{*}{ اندازه } & \multirow{2}{*}{ خر آورد } & \multicolumn{2}{|c|}{ حدود بوت استراب } & \multirow[t]{2}{*}{ متغير وابسته } & \multirow[t]{2}{*}{ متغير واسط } & \multirow[t]{2}{*}{ متغير مستقل } \\
\hline & & & حد يايين & حد بالا & & & \\
\hline$\cdot / \cdot \Delta$ & $\cdot / \cdot \sqrt{r}$ & $\cdot / \cdot \mathrm{WV}$ & $\cdot / \cdots 1$ & - MAF & اعتياد به اينترنت & عزت نفس & دشوارى در تنظيم هيجان \\
\hline$\cdot / \cdot \Delta$ &.$- / 1 Y 4$ & $\cdot / \mathrm{YA}$ & $-\cdot / \cdot \cdot r$ & $-\cdot / \Delta \cdot \Delta$ & اعتياد به اينترنت & عزت نفس & شفقت به خود \\
\hline
\end{tabular}

آسيب مىرسانند. افراد معتاد در شناسايى هيجانات خود و ديخران دجار مشكلاتى هستند كه باعث مىشود در برقرارى ارتباط عاطفى مثبت، سازنده و هدايت

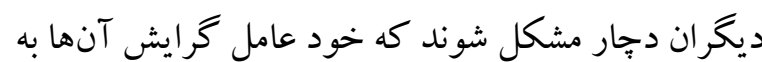
رفتارهاى اعتياد زا است.

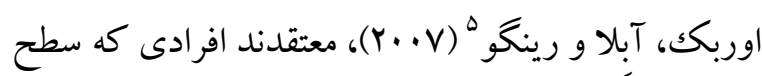
سطح بالايى از نقايص تنظيم هيجان را بروز مىدهند بيث از ديخران احتمال دارد در رفتارهاى برخطر كه به دنبال آن افسردگى يا اضطراب منجر مىشد، درگير شوند. طبق نظر اين بثزوهش كران افرادى كه راهبردهاى تنظيم هيجان ضعيف را فراخر فتهاند ممكن است بيش از ديخران مستعد استفاده از رفتارها برخطر بهعنوان ابزارى براى تسكين هيجانهاى منفى باشند. در نتيجه بر اساس نظر اين

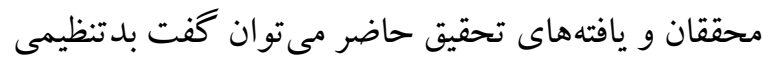

${ }^{5}$ Auerbach, Abela, Ringo
ئزوهش حاضر با هدف بررسى نقش واسطهاى عزت نفس در رابطه دشوارى در تنظيم هيجان و شفقت نسبت به خود با اعتياد به اينترنت انجام شد. نتايج يزوهش نشان داد كه بين دشوارى در تنظيم هيجان با اعتياد به اينترنت رابطه مثبت وجود دارد و دشوارى در تنظيم هيجان مىتواند مشكلات استفاده از اينترنت را بيشبينى كند. اين نتايج با يافته هاى ئزوهشهاى قبلى نتايج الله وردى

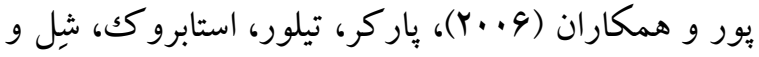

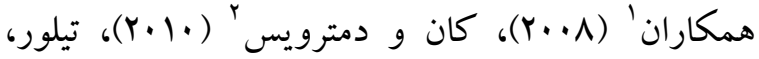

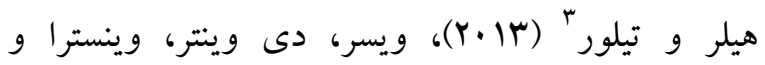
ورهالست ( (Y/ (Y) است. هيجانهاى مثبت، خودتنظيمى را تسهيل مى كنند و هيجانهاى منفى به خودتنظيمى

1 Parker, Taylor, Eastabrook, Schell \& etal

${ }^{2}$ Kun, Demetrovics

${ }^{3}$ Taylor, Hiller, Taylor

${ }^{4}$ Visser, de Winter, Veenstra, Verhulst 
ضرورى سلامت روان (مان، هوسما، شلما و دى

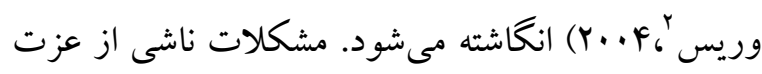
نفس ضعيف نه تنها منجر به درد و رنج فردى مىشود، بلكه هزينهاى نيز بر جامعه تحميل مى كند. بزوهشهاى

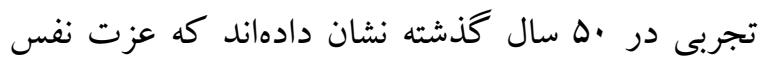
عامل روانشناختى مهمى براى سلامت و كيفيت زندكى است و منبع حمايتى مهمى در برابر رفتارهاى مخاطرهآميز

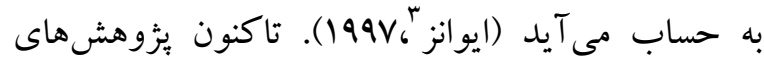
مختلفى جهت بررسى و ارزيابى اين عامل و رابطه آن با يا سلامت روان صورت گرفته است. يكى از حوزههايى كه هدف اين مطالعات بوده است، ارتباط عزت نفس با اعتياد

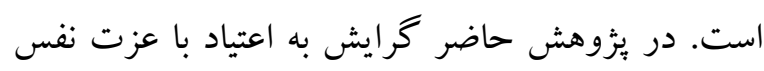

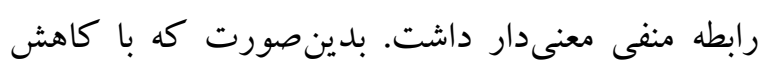
عزتنفس، گرايش به اعتياد بيشتر مىشود. اين يافته مطابق با ديخر يافتهاى مرتبط با اين زمينه است (دكل،

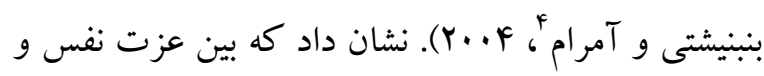
صفات شخصيتى با اعتياد به اينترنت رابطه وجود دارد.

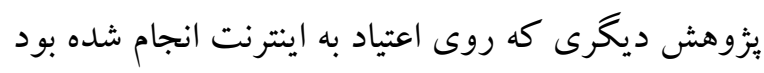
حاكى از اين بود كه افرادى با عزت نفس يائينتر زمان بيشترى را در اينترنت سيرى مى كنند (آرمستران، فيليسج

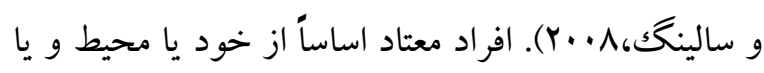
هر دو احساس ناخشنودى، نارضايتى و ناراحتى دارند و غالباً از احساس نامنى، بى كفى كفايتى، تنهايى، نفرت،

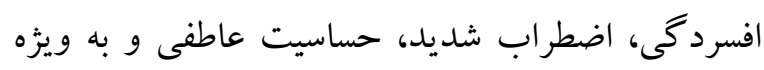
تعارضات درون فردى رنج مىبرند. احساس مى كنند قادر به حل مشكلات نيستند و گويى قادر نخواهند بود تا در آرامش و راحتى نسبى زندگى كنند (استيون، هوسير و

${ }^{2}$ Mann, Hosman, Schaalma \& De Vries

${ }^{3}$ Evans

${ }^{4}$ Dekkel, Benbenishty \& Amram
هيجانى عاملى در افزايش احتمال روآورى افراد به رفتارهاى برخطر از جمله اعتياد به اينترنت است. تحليل روابط ساختارى هم جنين نشان داد كه ابعاد شفقت به خود اعتياد به اينترنت را به صورت منفى بيشبينى

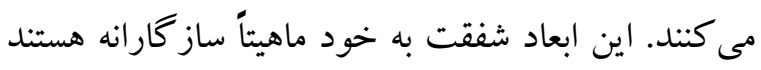
و آنها نشان مىدهند كه در تجربه هاى منفى زندگى إنى

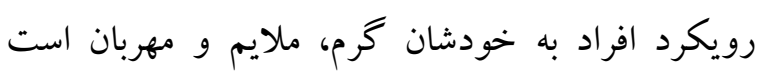
(نف، ب...Y)؛ او هم جنين بيشنهاد كرد كه شفقت به خود تأثيرات محافظتى منحصربه فردى را فراهم مى كند. يثزوهشها روى شفقت به خود به طور كلى نشان مىدهند

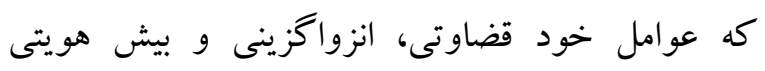
ارتباط مثتى با متغيرهاى منفى مثل اضطراب، افسردگى، روان رنجورخويى، نشخوار، خود انتقاد كرى دارد. به طور موازى، مطالعات روى اعتياد به اينترنت نشان داد كه اعتياد به اينترنت به صورت مثبت با كاهش تعاملات اجتماعى، افسردگى، تنهايى و كاهش عزت نفس ارتباط دارد.

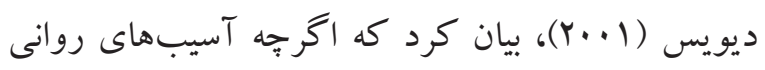
علتهاى دورى هستند، آنها به طور غيرمستقيم از طريق شناخت هاى ناساز گار، اعتياد به اينترنت را تحت تأثير قرار مىدهند. مطابق با مدل شناختى - رفتارى، اثر ميانجى بين آسيبهاى روانشناختى و اعتياد به اينترنت وجود دارد. اين، به تأثيرات ميانجى شناختهاى ناساز گار بلهويزه عزتنفس بِيين در اعتياد به اينترنت تأكيد مى كند. نتايج اين بزوهش تأكيد مى كند كه بايستى توجه بيشترى

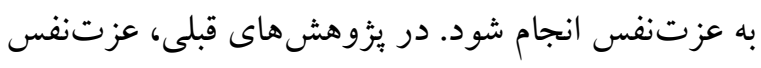
يايين يكى از عوامل مهم اعتياد به اينترنت (آيدين،

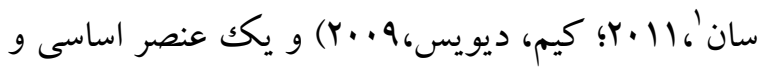

${ }^{1}$ Aydm\& San 
حاضر، مانع استنتاجهاى علّى و شناخت دقيق ماهيت واقعى روابط بين متغيرهاى يُزوهش مىشود. احتمال زيادى وجود دارد كه ترتيب زمانى شكل گيرى متغيرها بر اساس مدل فرضى ارائهده باشد؛ با وجود اين، قطعاً

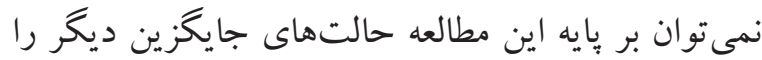
رد كرد. سرانجام اينكه در اين مطالعه براى ارزيابى هر كدام از متغيرها تنها از يك ابزار اندازه كيرى خود سنجى سنى استفاده شد. استفاده از روشهاى اندازهگيرى متنوع مى تواند به مفهومسازى بهتر متغير كمكك كند. با توجه به محدوديتهاى يزٔوهش، بيشنهاد مى شود مطالعه حاضر روى جمعيت بالينى يا جمعيتهاى غير دانشجويى نيز انجام شود تا توان تعميم دهى يافتهاى آن افزايش يابد.

\section{سياسگز ارى}

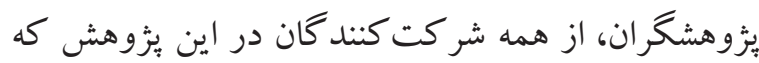
نهايت همكارى را در اجراى اين بزّوهش داشتهاند، تشكر

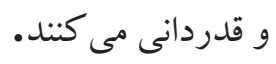

\section{References}

Aldao, A., Nolen-Hoeksema, S., \&Schweizer, S. (2010). Emotion- regulation strategies across psychopathology: A meta_analytic review. Clinical Psychology Review, 30, 217-237.

Allahverdipour, H.,shafii, F., Azad fallah, P.Emami, A. (2006).The statues of selfcontrol and its relation to drug abuse-related behaviors among Iranian male high School students, Social Behavior and Personality, 34(4), 413424

Amiri S, Sepehrian Azar F, Naseri Tamrin K. The role of cognitive emotion regulation srategies, impulsivity and extraversion in the tendency of the intermet addiction in the sudents of Urmia University. in 2014. Pajouhan Scientifc Journal. 2015;14(1):1-11.(Persian)
ميلز '11) اين موارد همان كونه كه در تحقيقات مختلف نشان داده شده است، همگیى مى تو انند بيامد منفى عزتنفس بائين باشند. يِيامدهاى عزتنفس منفى اغلب جندجانبه است. عزتنفس ضعيف مىتواند به نا ارزنده سازى شخصى، ايجاد نگرشهاى مخرب، آسيبيذيرى روانيزشكى، مشكلات اجتماعى و رفتارهاى برخطر از

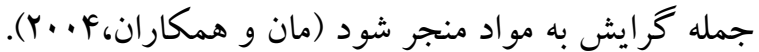
اين مطالعه هم جنين مى تواند نكاتى كاربردى براى يشيخيرى از اعتياد به اينترنت داشته باشد. از آن جا كه دانش آموزانى كه وابسته به اينترنت هستند، معمولاً در زندگى روزمره از مشكلات، عملكرد مدرسه، روابط

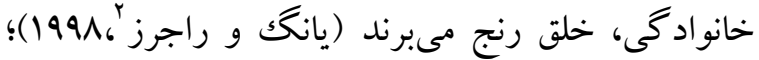
بنابراين مهم است كه متخصص هاى سلامت روان راهبردهاى مداخلهاى براى بيشخيرى از اعتياد به اينترنت

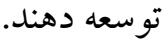

\section{نتيجه كيرى}

با اين كه يافتهها از مدل فرضى يثزوهش حمايت كردند، نتايج اين يزوهش بايد با در نظر كرفتن محدوديتهاى آن تفسير شود. ابتدا اينكه مطالعه حاضر روى دانشجويان

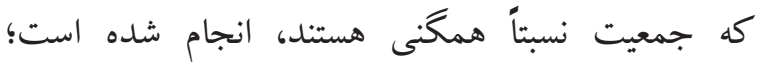
بنابراين، در تعميم نتايج به جمعيتهاى ديخر محدوديت وجود دارد. از سويى، هرجند بسيارى از بثزوهشخران از مفهومسازى اختلالات روانى در ساختارى ابعادى حمايت مى كنند و بر اين باورند كه نتايج به دست آمده از محيطهاى بالينى و غير بالينى تا حد زيادى مطابق هم هستند. بايد در تعميم نتايج اين مطالعه به محيط بالينى احتياط كرد. محدوديت ديخر اينكه ماهيت مقطعى مطالعه

\footnotetext{
${ }^{1}$ Steven, Hosier \& Miles

${ }^{2}$ Young, Rogers
} 
Amsadter A. Emotion regulation and anxiety disorders. Journal of Anxiety Disorders. 2008;22(2):211 221.

Armstrong, L., Phillips, J. G., \& Saling, L. L. (2000). Potential determinants of heavier intemet usage. International Joumal of HumanComputer Studies, 53 (4), 537-550.

Auerbach, R.P., Abela, J. R. Z, Ringo Ho, M. (2007). Responding to symptom of depression and anxiety: Emotion regulation, neurotism and engagement in risky behaviours. Behaviour research and therapy, 45, 2182-2191.

Auerbach, R.P., Abela, J. R. Z, Ringo Ho, M. (2007). Responding to symptom of depression and anxiety: Emotion regulation, neurotism and engagement in risky behaviors.Behavior research and therapy, 45 , 2182-2191.

Aydm, B., \& San, S. V. (2011). Intemet addiction among adolescents: The role of self-esteem. Procedia- Social and Behavioral Science, 15, 3500-3505.

Bentler, P. M.(1995). EQS Structural Equations Program Manual. Encino, CA: Multivariate Software.

Breines JG, Chen S. Self-compassion increases selfimprovement motivation. Personality and Social Psychology Bulletin 2012; 38(3):11331143.

Chou, C.P., Bentler, P. M.(1995). Estimates and tests in structural equation modeling. In R. H. Hoyle, Structural equation modeling: Concepts, issues and applications. Califomia: Sage.

Davis, R. A. (2001). A cognitive-behavioral model of pathological intemet use. Computers in Human Behavior, 17, 187-195.

Dekkel, R., Benbenishty, R., \& Amram, Y. (2004). Therapeutic communities for drug addicts: Prediction of long-term outcomes. Addictive Behaviors, 29 (2), 1833-1837.

Evans, D. R. (1997). Health promotion, wellness programs, quality of life and the marketing of psychology. Canadian Journal of Psychology, $38(1), 1-12$.
Gratz, K. L., \& Roemer, L. (2004). Multidimensional assessment of emotion regulation and dysregulation: Development, factor structure, and initial validation of the difficulties in emotion regulation scale. Joumal of Psychology and Behavioral Assessment, 26(1),41-54.

Intemet World Statistics. (2015). Jordan Internet Usage and Telecommunications Report. Retrieved from.

Jang, K. S., Hwang, S. Y., \& Choi, J. Y. (2008). Intemet addiction and psychiatric symptoms among Korean adolescents. Joumal of School Health, 78(3), 165-171.

Jia, J., Li, D., Li, X., Zhou, Y., Wang, Y., Sun, W.(2017). Psychological security and deviant peer affiliation as mediators between teacherstudent relationship and adolescent Intemet addiction. Computers in Human Behavior 73,PP: 345-352.

Kim, H. -K. \& Davis, K. (2009). Toward a comprehensive theory of problematic Intemet use: Evaluating the role of self-esteem, anxiety, flow, and self-rated importance activities. Computers in Human Behavior, 25, 490-500.

Kline RB.(2001). Principles and practice of structural equation modeling .3nd Ed. New York: Guilford.

Kline RB.(2010). Principles and practice of structural equation modeling. New York: Guilford.

Kret DD. The qualities of a compassionate nurse according to the perceptions of medicalsurgical patients. MEDSURG Nursing 2011; 20(1): 29-36.

Kubota, Y., \& Sasaki, S. (2002). Aerobic exercise and self-esteem in children. Joumal of Behavioral Medicine, 24 (12), 12735.

Kun, B., Demetrovics, Z (2010).Emotional intelligence and addictions. Subst Use Misuse, 45(8), 131-60.

Leary MR, Tate EB, Allen AB, Adams CE, Hancock J. Self-compassion and reactions to unpleasant self-relevant events: The implications of treating oneself kindly. Joumal of personality and social psychology 2007; 92(5): 884-907. 
Leen S, Tessai W. Pathological gambling in eating disorders, and psychoactive subsance use disorders. Joumal of Comorbidity of Addictive and Psychiatric Disorders. 2002;25(6):89-102.

Malak, M. Z., Khalifeh, A. H., Shuhaiber, A. H.(2017). Prevalence of Internet Addiction and associated risk factors in Jordanian school students. Computers in Human Behavior, Volume 70, PP: 556-563.

Mann, M., Bosman, C. M., Schaalma, H. P., \& de Vries, N. K. (2004). Self-esteem in a broadspectrum approach for mental health promotion. Health Education Research, 19, 357-372.

Mann, M., Hosman, C.M.H., Schaalma, H.P., \& De Vries, N. (2004). Self-esteem in a broadspectrum approach for mental health promotion. Health Education Research, 19(4), 357-72.

Mcauley, E., Mihalko, SL., \& Bane, SM. (1997). Exercise and self-esteem in middle-aged adults: multidimensional relationships and physical fitness and self-efficacy influences. Joumal of Behavioral Medicine, 20(9), 67-83.

Myberg, L. (2011). Forgiveness as a mechanism of selfregulation: An ego depletion model. Unpublished dissertation in psychology, University of Richmond.

Neff, K. D. (2003). Self-compassion: An alternative conceptualization of a healthy attitude toward oneself. Self and Identity, 2(2): 85-101.

Neff, K. D. (2003). The development and validation of a scale to measure self-compassion. Self and Identity, 2, 223-250.

Orsal, O., Orsal, O., Unsal, A., Ozalp, S.(2013). Evaluation of Internet Addiction and Depression among University Students Original Research Article Procedia - Social and Behavioral Sciences, Volume 82, 3, PP:445-454

Parker, J.D., Taylor, R.N., Eastabrook, j.M., Schell, S.L., Wood, L.M. (2008). Problem gambling in adolescence: Relationships with internet misuse sgaming abuse and emotional intelligence. Personality and Individual Differences, 45, 174-180.

Poor Ramazan M.(2006). Examine the relationship between intemet addiction and Mental Health on the SCL-90-R tes in persons to the internet centers of Mashhad in the second half of 2005. [Ph.D. Thesis]. Mashhad: Department of Medical Sciences, University of Azad Mashhad.(Persian)

Preacher, K. J., \& Hayes, A. F.(2008). Asymptotic and resampling strategies for assessing and comparing indirect effects in multiple mediator models. Behavior Research Methods. 40, 879891.

Soltani M, Fooladvand Kh, Fathi-Ashtiani A. Relationship between identity and sensationseeking with intemet addiction. Joumal of Behavioral Sciences. 2010;4(3):191-197. (Persian)

Steven, G., Hosier, W., \& Miles, C. (2011). Personality and motivational correlates of alcohol consumption and alcohol-related. Addictive Behaviors, 36(1), 87-94.

Szczygie D, Buczny J, Bazinska R. Emotion regulation and emotional information processing: the awareness. Joumal of Personality and Individual Differences. 2012;52(3):433-437.

Taylor,L., Hiller, M., Taylor,R. B. (2013).Personal factors and substance abuse treatment program retention among felony probationers: Theoretical relevance of initial vs. shifting scores on impulsivity/low selfcontrol. Journal of Criminal Justice, 41(3), $141-150$

Visser,L., de Winter,A. F., Veenstra,R.,Verhulst,F.C., Reijneveld,S.A.(2013).

Alcohol use and abuse in young adulthood: Do self-control and parents' perceptions of friends during adolescence modify peer influence? The Trails study. Addictive Behaviors, 38(12), 2841-2846.

Yagobi H, Zardkhaneh Akbari S, Vaghar Anzabi M. Final report of examination universities under the minisry of science, research and technology about mental health in sudents incoming 2009-2010, with partnership 
counseling centers of sudent in universities under the minisry of science, research and technology 2010. (Persian).

Yi-Ping, H., Shen, A. C., Wei, H.S., Feng, J.Y., Huang, C.Y.(2015).Associations between child maltreatment, PTSD, and intemet addiction among Taiwanese students, Computers in Human Behavior 56, PP:209-214.

Young, K. S., \& Rogers, R. C. (1998). The relationship between depression and internet addiction. Cyber-Psychology \& Behavior, 1, 25-28. 